J. of Modern African Studies, 54, 2 (2016), pp. 317-338 C Cambridge University Press 2016. This is an Open Access article, distributed under the terms of the Creative Commons Attribution licence (http://creativecommons.org/licenses/by/4.o/), which permits unrestricted re-use, distribution, and reproduction in any medium, provided the original work is properly cited.

doi:10.1017/Soo22278X16000197

\title{
The role of the non-farm sector in rural development in Lesotho
}

\author{
TŠEPISO A. RANTŠO \\ Department of Development Studies, National University of Lesotho, \\ P.O. Roma I 80 , Lesotho
}

Email: at.rantso@nul.ls / rantsot@yahoo.com

A B S T R A C T

This paper assesses the role of the non-farm sector in rural development in Lesotho. Evidence from studies in developing countries indicates that agriculture was formerly used as the main source of livelihood for many people in poor countries. However, due to the decline in agricultural productivity (which results in poverty and food insecurity) caused by unfavourable agroclimatic conditions, many people are turning to non-farm activities as a means of making a living. Therefore, non-farm incomes are used to provide the means of sustenance for many people. However, little attention has hitherto been paid to improving the rural non-farm sector as an alternative or complementary rural development strategy in Lesotho. This research paper uses quantitative research methods to analyse the available data. The main research findings suggest that many people make a living out of non-farm incomes. As a result, this paper proposes that the rural non-farm sector should be given more priority by the government in rural development in Lesotho.

\section{N T R O D U C T I O N}

Rural areas of developing countries are confronted with many challenges including poverty, unemployment and food insecurity (see Dixon 1990). These social problems are attributed to the decline in agricultural productivity due to agro-climatic conditions (Reardon 1997) and other economic factors such as reduction of agricultural subsidies to small scale farmers by governments. Low agricultural production has forced many people to participate in non-farm agricultural activities/the rural non-farm sector to make a living. According to Lanjouw \& Lanjouw (1997), the rural non-farm sector can be defined as all 
income generating activities including income in-kind that are not agricultural but are located in rural areas. In addition to this definition, Reardon (1997: 737) defines non-farm income as income from local non-farm wage employment, local non-farm self-employment, and migration income. Tacoli (1998: 158) further says non-agricultural rural activities include non-farm activities which are carried out in the farm but are not related to crop production. The rural non-farm sector entails a diversity of activities that includes commerce, manufacturing and services (Nowak 1989).

Many people participate in rural non-farm activities to diversify their livelihood options. According to Ellis (1998) the rural non-farm sector ensures diversification of incomes among the rural households. People make a living out of different activities such as tailoring, weaving, carpet making, blacksmithing, carpentry and many others (see Kristiansen 2003; Idowu et al. 2011). In some households, the incomes derived from these activities supplement those from agriculture, while in some families rural non-farm activities are the main source of income. According to Start (2001) 'diversification can refer to a shift away from traditional rural sectors, such as agriculture, to non-traditional, often non-agricultural activities'. On the other hand, Malek \& Usami (2009: 143) define diversification as an increase in the number of household income components. It can be argued that diversification of the livelihood options ensures food security among the poor households. In this respect, livelihood or income diversification in the rural areas is considered as a pathway out of poverty by both men and women.

This paper is organised as follows: the first part studies the role of nonagricultural activities in the development of some African countries. The second section looks at the economic dependence of Lesotho on South Africa for employment opportunities through the migrant labour system. The paper further looks at the rural development programmes in Lesotho. This section focuses on agricultural rural development programmes that were implemented to increase food production in the country. The paper then examines the research methods used in the study and presents the results. Finally, the paper makes conclusions based on the main findings of the study.

THE ROLE OF NON-AGRICULTURALACTIVITIES IN DEVELOPMENT I N A F R I C A

There are differing reasons for people to participate in rural non-farm activities. The most common reason is poverty. It is stated that many 
people are forced into the non-farm sector involuntarily by poverty (Jin et al. 2005). In order to cope with poverty, some people diversify their livelihood options (Ellis 1998). Livelihood diversification is meant to ensure the security of livelihoods in households in order to reduce poverty. Traditionally, rural people rely mostly on agriculture for survival. However, when agriculture fails to give satisfactory returns because of risks, such as unfavourable agro-climatic conditions (Kelly et al. 1994; Kuiper et al. 2008), people tend to resort to non-farm activities for survival (Reardon 1997; Ellis 2000; Berdequé et al. 2007). For example, in Mozambique, people participate in non-farm activities, such as bicycle and radio repairs, because of drought (Cunguara et al. 2011). Some people are forced into participating in non-agricultural income-generating activities because of declining agricultural productivity caused by congestion on agricultural lands (Davis 2003). Some studies show that increasing population pressure on agricultural lands has forced some people to participate in the non-farm sector (Beyene 2008) because of the scarcity of arable land. It is further stated that in Ethiopia, land scarcity and the increasing fragmentation of land make non-farm activities an alternative source of livelihood (Holden et al. 2004).

The contribution of non-farm activities to rural development in African countries cannot be overestimated. The rural non-farm sector contributes to rural development in the poor countries in different ways. First, the rural non-farm sector contributes to poverty reduction and employment creation. Non-farm enterprises address poverty and provide employment opportunities to people who cannot secure employment in the formal sector (Chuta \& Liedholm 1979) to satisfy their basic needs such as food, shelter and clothing. According to Stifel (2010), in Madagascar poverty rates are very high among people who labour in agriculture $(78 \%)$ compared with those that rely on the non-farm sector $(39 \%)$. In order to illustrate the importance of nonfarm activities to employment creation, research shows that the rural non-farm sector employs about $20 \%$ of the labour force in north Africa and $10 \%$ in Africa generally (Haggblade et al. 2010). Studies also show that the rural non-farm sector is an important employment source for women (Arghiros \& Moller 2000). Female participation in rural non-farm activities is very high in some African countries. For instance, in Ghana women working in the non-farm sector make up $46 \cdot 5 \%$ (Dary \& Kuunibe 2012).

Second, the importance of non-farm rural activities in income generation in some African countries is significant. Research indicates that on 
average, people earn higher incomes in non-farm activities than in agriculture (Jonasson \& Helfand 2oog). For example, a study in south-west Nigeria illustrates that non-farm incomes constitute $67 \cdot 1 \%$, while farm incomes make only 32.9\% of total incomes (Awoyemi et al. 2011). A study in Madagascar shows that, on average, households derive $22 \%$ of their incomes from non-farm activities while individuals derive only $20 \%$ (Stifel 2010).

Third, according to Lanjouw (1999), income distribution in the nonfarm sector is associated with the type of activities. Some activities are of high labour productivity and lead to high incomes, while others are of low labour productivity and are taken only as a residual source of employment or as a last resort (Sundaram-Stukel et al. 20o6). People who fall into the latter category of least paying activities are mostly women (Lanjouw 1999; Balisacan et al. 2000) because many of them lack capital and education (Dary \& Kuunibe 2012) that would allow them to participate in higher paying activities. For instance, in Zimbabwe male entrepreneurs are found in all different types of enterprises while female entrepreneurs operate businesses in crafts, restaurants, hair salons, dressmaking, trading, office services and others (see Zuwarimwe and Kirsten 2011). The male-owned enterprises are found to perform better (in terms of average value/turnover) than the ones owned by their female counterparts (Zuwarimwe and Kirsten 2011 ).

The above discussion centred on the importance of rural non-farm activities to increase poverty reduction in developing countries. Many people participate in the sector when they cannot secure employment in the formal sector. Therefore, contribution of non-farm activities to poverty and employment creation is very important.

The farm sector has played an important part in rural development of many African countries, and Lesotho is not an exception in this regard. However, the contribution of the farm sector to poverty reduction, employment creation and ensuring food security has been in decline over the past decades. This decline is due to decreasing agricultural productivity caused by severe droughts, soil erosion and many other factors. Therefore the non-farm sector is considered as an alternative rural development strategy where agriculture has failed to provide the means of a living. Research in Lesotho shows that non-agricultural activities are the main source of livelihood because subsistence agriculture has failed to ensure food security among rural households. It is further stated by some scholars such as Ferguson (1985), Low (1986) and Modo (2001) that decline in agricultural productivity has contributed to labour migration between Lesotho and South Africa. Therefore, 
economic dependence of Lesotho on South Africa for employment opportunities, foodstuffs and other economic goods can be linked to low agricultural production. In the light of this, the following section studies the origin of economic dependence of Lesotho on South Africa, especially on employment opportunities.

THE MIGRANT LABOURER SYSTEM BETWEEN LESOTHO AND S O U T H A F I C A

The dependence of Lesotho on South Africa for employment is commonly noted in the literature. Cobbe (1983) states that the majority of rural areas in Lesotho have interacted economically with South African market towns, urban centres and mines that employ Basotho migrant workers. Makhanya (2004) estimates that only 10 per cent of the active labour force is absorbed in Lesotho, with the remaining percentage working in South African industries, mines and on farms or plantations. The nature of this dependence is such that Ward (1967) considers Lesotho to be an economic hostage to South Africa. The rural areas of Lesotho are seen as the reserve army or source of cheap labour for South African commercial farms (permanent workers and seasonal migrants) and mines. The migration of Basotho men to South African mines can be associated with the country's closeness to South Africa and the lack of mining opportunities in Lesotho (Modo 2001; Crush 2002).

The origin of Lesotho's economic dependence on South Africa for employment can be traced far back during the discovery of diamond mines in Kimberly. Research shows that Lesotho was once a granary for South Africa, supplying grain mainly to the Kimberly diamond mines in the 1870s (Murray 1981). These findings suggest that the number of Basotho men working in South African mines at that time was very low. However, the downturn in trade relations between South Africa and Lesotho occurred during the introduction of tariffs to grain produced by Basotho farmers in the 1880 os. This reduced the market for grain produced in Lesotho. As a result, migration of Basotho seeking employment opportunities in the South African mines started (Rosenberg 2007).

There are some contrasting views on the causes of labour migration between Lesotho and South Africa in the past years. These views relate to the decline in agricultural productivity in Lesotho. According to Ferguson (1985: 649), 'Lesotho is a labour reserve for the South 
African economy, not a subsistence or peasant economy'. This view suggests that agriculture does not form the main livelihood activity in Lesotho because many people make a living out of the migrant labourer remittances. According to Modo (2001), labour migration from Lesotho to South Africa started with the discovery of diamonds in the Orange Free State in 1867 and the opening of gold mines in the Transvaal in 1886. The majority of migrants to South Africa originated from Lesotho and Mozambique (Modo 2001). There were some factors that contributed to the migration of people from other southern African countries to South Africa. McDonald et al. (2000) state that cross-border migration in Southern Africa is a complex issue associated with the need for cheap labour for South African mines and agriculture, while Modo (2001) indicates that Basotho migrate into South Africa because of the declining agricultural production in their own country; this contention further leads to the argument by Ferguson \& Lohmann (1994) that Lesotho is not a peasant economy because labour migration occurred at the time of agricultural decline.

Labour migration from Lesotho to South Africa is mainly caused by some push factors, especially the decline in agricultural productivity in Lesotho; while the pull factors are the South African mines, agriculture and industries (Wallman 1976; Elkan 1980; McDonald et al. 2000). It has been noted in the research that the push factor is the main cause of labour migration from Lesotho to South Africa because rural people mainly perceive migration as a comparative advantage (Low 1986). For example, the FAO (1977) observed that many people in the Senqu River Valley Integrated Rural Development Project had no interest in farming and many able-bodied men migrated to South African towns and mines in search of better paying jobs. Consequently, farming was left in the hands of children and old people. Therefore, an assertion that many Basotho migrate to South African gold mines to supplement agricultural incomes does not hold (Spiegel 1980). Remittances as a result of migration to South African gold mines, farms and industries have been the main source of subsistence and rural development in Lesotho (Murray 1977; Modo 2001; Ulicki \& Crush 2007). The migrant labourer remittances are used to finance agriculture and other development activities in Lesotho (Wallman 1972; Low 1986).

The migrant labourer remittances constitute important aspects of non-agricultural incomes in many countries. However, the contribution of migrant labourer remittances to rural development in Lesotho has been in decline since the late 1980 os and early 199os (see Rantšo 
2014). This is caused by downsizing in the South African goldmines (Marais 2013). Retrenchment of many Basotho men from the South African goldmines contributes to the high unemployment rate in the country. In this regard, rural non-farm activities are considered important livelihood options for the retrenched mine workers.

RECENT DEVELOPMENTS IN LABOUR MIGRATION FROM LESOTHO

The pattern of migration appears to have changed in recent years. In the past, migration was largely restricted to men working in the mines. However, studies show that nowadays people from Lesotho migrate to South Africa for different reasons, such as for shopping, business, study, holidays, visiting relatives and seeking employment opportunities (Crush 2002). The migration of Basotho into South Africa can be classified as both legal and illegal migration. The migration to work in South African mines, farms and agriculture is, in the main, legal (Ulicki \& Crush 2000). Ulicki \& Crush (2000) point out that in 1998 there were about 7,00o legal migrants from Lesotho working on South African plantations and on Free State farms. However, illegal migrants also work on plantations and for construction companies, together with a large number of illegal women migrants working as domestic workers in South Africa (Crush et al. 2010).

There are varying reasons why large numbers of women migrate to South Africa. For Wilkinson (1983), Modo (2001) and Crush \& McDonald (2000), the major reason is the demise of the apartheid regime in which many Basotho women were prohibited by the black labour laws from moving with their husbands to South African mines. However, from 1990 onwards, many women found it easy to migrate to South Africa for employment opportunities and to escape poverty (Crush et al. 2010). Evidence from the study by Crush et al. (2010) shows that women migrants from Lesotho contribute a higher percentage, at $16 \cdot 4 \%$, of all incoming female migrants than do other southern African countries such as Mozambique, Swaziland and Zimbabwe.

Dependence of many Basotho for employment in the South African mines is illustrated by the fact that herding and working on the family farms are not considered employment, but employment in the mines is considered work (Mensah \& Naidoo 2011). Migration of many Basotho (both men and women) illustrates that agriculture is no longer considered the main source of livelihood by many Basotho. Therefore, the rural non-farm sector can be seen as an alternative or 
complementary rural development strategy to agriculture. Rural nonfarm activities can fill the gap that is left by agriculture as far as employment creation is concerned.

It can be noted from the above discussion that, there are some contradicting views on the causes of labour migration between Lesotho and South Africa. The most common view links migration of Basotho into South Africa to the decline in agricultural production, while a contrary argument says migration of Basotho men into South Africa causes decline of agriculture. Despite these arguments, the Lesotho government has been working with development organisations and bilateral institutions to improve productivity in agriculture through implementation of area based development projects since independence. Although increasing productivity in agriculture started during the colonial period, most colonial rural development projects focused on reducing soil erosion by adopting anti-erosion control measures such as reduction of livestock numbers and introduction of rotational grazing (Driver 1999; McCann 1999). The blame for erosion of the rangelands was placed on the practices of livestock farmers (Quinlan 1995). The following section looks mainly at the Thaba-Tseka Integrated Rural Development Project, as a rural development programme implemented to increase agricultural productivity and ensure food security among Basotho households.

RURAL DEVELOPMENT PROGRAMMES IN LESOTHO

Some of the rural development programmes and projects in Lesotho aimed at increasing productivity in agriculture were implemented through area based or Integrated Rural Development Projects in the 1970 and 1980s. These include, among others, Thaba Bosiu, Khomokhoana, Matelile and Thaba Tseka Integrated Rural Development Projects. This paper will focus mainly on the latter area based agricultural development programme.

\section{Thaba-Tseka Integrated Rural Development Project}

According to Ferguson (1990), in November 1974 the mission of delegates from the Food and Agricultural Organization (FAO)/World Bank and Canadian Development Agency (CIDA) visited Lesotho to prepare together with the Government of Lesotho the first phase of the mountain area development project. The project was supported by the 
Lesotho government and the World Bank through the International Development Agency (IDA) and Canadian International Development Agency (CIDA). The total amount of money that supported the project was US $\$ 15$ million, where CIDA contributed US\$6 million, the World Bank US $\$ 5.5$ million, ODM US $\$ 1.5$ million while the Lesotho government contributed US\$2.4 million. According to Ferguson (1990), the Thaba-Tseka Integrated Rural Development Project was established on the assumption that the mountain areas are less exploited compared with the lowlands. The project focused on livestock production, range management and crop production. The crop production unit urged farmers to shift away from producing some traditional crops such as maize and sorghum to production of cash crops such as wheat and peas (Ferguson 1990).

Besides improving agricultural production in the mountain areas of Lesotho, Thaba-Tseka Integrated Rural Development Project was also a form of decentralisation, and established Thaba-Tseka as the tenth district. Therefore, road networks that linked the lowlands with the mountain areas were constructed. The idea was to facilitate easy transportation of agricultural inputs and marketing of farm products. The Thaba-Tseka Integrated Rural Development Project was meant to avoid the major problems that faced the lowlands agricultural development project. Therefore, farmers were supplied with necessary agricultural inputs (Ferguson 1990).

The project also assisted farmers to produce forage for livestock. As a result, low cost techniques for producing and improving forage were introduced. In addition to producing forage for livestock, conservation of the degraded rangelands was on the agenda of this mountain project. Conservation of the rangelands was achieved through establishment of grazing associations that established blocs to avoid overgrazing (see Ferguson 1990).

The Thaba-Tseka Integrated Rural Development Project faced the same challenges that other projects were confronted with. It is stated that lack of community participation in the decision-making process was the main challenge. For instance, Thaba-Tseka Integrated Rural Development Project introduced cash crops while the local people were in need of health services (see Ferguson 1990). As a result, participation from the local people was very low. Lack of community participation in area-based development projects was also observed elsewhere in Lesotho. According to FAO (1977), the Senqu River Valley Integrated Rural Development Project was faced with lack of labour in bloc farming. This is because the young people were not interested in 
farming but finding employment opportunities in the South African mines. As a result, farming was left in the hands of young and old people.

\section{RESEARCH METHODS}

The study was conducted in the six districts of Lesotho: Butha-Buthe, Leribe, Berea, Maseru, Mafeteng and Mohales' Hoek. Data were collected from the three main sectors of non-farm activities. About $4^{\mathrm{O}}$ enterprises were interviewed from trade and commerce (guest houses and lodges; retail shops/general dealers; fruit and vegetable shops; bottle stores and restaurants). In manufacturing, 45 enterprises were interviewed (brick-making, carpentry, welding, weaving, tombstone construction, bakeries, milling, dressmaking, tailoring) and five agro-processing enterprises were also interviewed (canning; milling; packaging; dairy). Under the service subsector, 35 enterprises were interviewed (traditional healing; herb selling; hair salons; public phones; motor mechanics; shoe repairs; clinics; surgeries; car washes; panel beating and spray painting; radio, TV and DVD player repair). As a result, the total number of rural non-farm enterprises interviewed was 125 . The technique of Simple Random Sampling (SRS) was used to collect data. Different rural non-farm enterprises were chosen at random. Under the SRS sampling procedure, the respondents had an equal chance of being selected. Data were captured with a spreadsheet (Microsoft Excel) and analysed using tables and figures. This package enabled cross-tabulation of some variables.

R E S U L T S

Main source of livelihood for people participating in the rural non-farm sector

Research in developing countries suggests that a mix of income derived from agriculture and from non-farm income is common (Reardon 1997). It is important to establish the percentage that non-farm or farm incomes contribute to the livelihoods of the respondents. Against this background, the percentages that farm and non-farm sources of incomes contribute to the livelihood of the respondents are presented in Table I.

It is evident from Table I that respondents derived a significant percentage of their livelihood from non-farm incomes. In this respect, the results indicate that respondents derive an average of $57.0 \%$ of their livelihood from non-farm incomes, while agriculture accounts for 
TABLE I

Average percentage of livelihood derived from different livelihood sources in Lesotho, 2010

\begin{tabular}{lc}
\hline \hline Type of livelihood & Average $\%$ \\
\hline Non-farm business income from this business & $35 \cdot 3$ \\
Non-farm business income from other businesses & $21 \cdot 7$ \\
Farming income: crops & $8 \cdot 1$ \\
Farming income: stock & $10 \cdot 4$ \\
Assistance/remittances from family/friends & $24 \cdot 7$ \\
Social transfer from government (e.g. pensions) & 0 \\
Total & $100 \cdot 0$ \\
\hline \hline
\end{tabular}

Source: Field data.

$18.5 \%$ of their livelihood. The high average percentage of incomes derived from the non-farm sector can be explained by low agricultural productivity that often results in food insecurity in Lesotho. In this regard, one respondent affirmed: 'Agricultural production could not sustain my family for over six months after harvest, and I use non-farm business incomes to meet the needs of the family' (Morake 2010 int.). A full discussion of the reasons for the decline in agricultural productivity is not within the scope of this paper but overall, it is commonly related to the migration of many Basotho men to the South African mines (Wallman 1972; Ferguson 1985), drought and soil erosion (Wellings 1986) and the Structural Adjustment Programmes in the early 1990s, which meant that farmers could not access agricultural subsidies (Makenete et al. 1998). At the same time, it should be acknowledged that a symbiotic relationship existed between migrant labourer remittances and agriculture in Lesotho (Wallman 1972).

Although the statistics show that agriculture employs more than $70 \%$ of rural people in Lesotho (Central Bank of Lesotho 2003), the value of non-farm employment should not be underestimated. It is evident from Table I that many people derive a large percentage of their livelihood from non-farm business incomes relative to agricultural incomes. These findings are in line with the international trends that, on average, people earn higher incomes from non-farm activities than from agriculture (Jonasson \& Helfand 2009). However, evidence shows that agriculture is considered the main source of livelihood elsewhere, but in Lesotho, non-farm incomes are the main source of livelihood. Therefore, it is correct to argue that for many people, non-farm business incomes in Lesotho can be considered the main sources of 
livelihood, while agricultural incomes are supplementary. This point is supported by the fact that many Basotho work as migrant labourers in South Africa (although recent studies show declining number of Basotho men working in the mines because of high retrenchment). As a result, the migrant labourer remittances are used to support the households. This shows that migration remittances as a component of nonagricultural activities play an important part in rural development in Lesotho.

HOUSEHOLD EXPENDITURE OF RURAL NON-FARM INCOMES

According to Reardon (1997) rural non-farm incomes are used to cater for different households needs, especially financing agriculture. The respondents were asked to state how they spent their non-farm incomes, and the results are presented in Table II.

The data in Table II support the international trends that non-farm incomes are used to improve the living standards of people. It is evident from Table II that a significant amount of the average nonfarm incomes are used to meet the basic needs of people, such as clothing, food, education and others. The results reveal that on average, the respondents use $\mathrm{M}_{15} \mathrm{Oo} \cdot 00$ for tertiary education. Although the Lesotho government sponsors tertiary education, there are some people who are self-sponsored. The large amount of money used for tertiary education can be explained by the high fees charged at tertiary institutions. One respondent who spends some of her non-farm income on education of her children said: 'A large part of the income that I get from my hair salon is spent on education of my two children' (Mohai 2010 int.). It can also be observed that many respondents use $\mathrm{M}_{597 \cdot 94}$ on average for clothing. Most of the clothing items are imported into the country which increases the costs of clothing. In addition, many people spent a lot of money on clothing during the cold season, in winter. Table II further reveals that many people use $\mathrm{M}_{415}{ }^{138}$ on average for food. Lesotho is often faced with food shortages mainly during the dry season, when availability of food is very scarce. One respondent who uses some of his money for purchasing foodstuffs for his family said: 'Prices on foodstuffs often go up during the dry season. So, I use the income obtained from my welding workshop to purchase food for my family' (Ralejoe 2010 int.). Research in Lesotho suggests that low agricultural production causes food insecurity. Therefore, many people spend their incomes on foodstuffs (Sebotsa \& Lues 2010). Thus, these results show that non-farm incomes play an important part 
TABLE II

Household expenditure of non-farm incomes in Lesotho, 2010

\begin{tabular}{|c|c|c|c|}
\hline Item & $\begin{array}{l}\text { Average expenditure } \\
\text { in Maloti }\end{array}$ & Item & $\begin{array}{l}\text { Average expenditure } \\
\text { in Maloti }\end{array}$ \\
\hline Housing & o & Pay back loan & Mio75.00 \\
\hline Rental & $\mathrm{M}_{3} 68 \cdot 67^{1}$ & Health care & $\mathrm{M} 84 \cdot 12$ \\
\hline Bond & o & Paraffin/fuel & M145.95 \\
\hline Clothing & $\mathrm{M}_{597 \cdot 94}$ & Alcohol & $\mathrm{M}_{13} 8 \cdot 4^{2}$ \\
\hline $\begin{array}{l}\text { Education - } \\
\text { after-care }\end{array}$ & $\mathrm{o}$ & Smoking & $\mathrm{M} 61 \cdot 9 \mathrm{O}$ \\
\hline Pre-school & $\mathrm{M}_{127} \cdot 80$ & Food & $\mathrm{M}_{415} \cdot 38$ \\
\hline Primary school & M133.00 & Transport & $\mathrm{M} 283 \cdot 36$ \\
\hline Secondary school & $\mathrm{M}_{339 \cdot 22}$ & Telephone & M8o $\cdot 74$ \\
\hline Tertiary & $\mathrm{M}_{15} \mathrm{OO} \cdot 00$ & $\begin{array}{l}\text { Support for family } \\
\text { elsewhere }\end{array}$ & $\mathrm{M}_{322} \cdot \mathrm{OO}$ \\
\hline Rates & o & Entertainment & $\mathrm{o}$ \\
\hline Water and electricity & Mi66.81 & & \\
\hline Sub-total & $\mathrm{M}_{3233 \cdot 44}$ & & M26o6.87 \\
\hline $\begin{array}{l}\text { TOTAL } \\
\text { EXPENDITURE }\end{array}$ & & $\mathrm{M}_{5} 840 \cdot 31$ & \\
\hline
\end{tabular}

Source: Field data.

in meeting the basic needs of people. Evidence reveals that non-farm incomes are used to improve the living standards of people by ensuring the availability of food, shelter and the payment of school fees (Hymer \& Resnick 1969). Therefore, these results are in line with international trends that rural non-farm incomes are in a position to reduce poverty.

It is stated that small-scale non-farm enterprises employ many people with a low level of education. However, the level of education of the owner of the enterprise has an impact on its performance (enterprise). In this regard, the following section looks at the level of education of the owner and performance of the enterprise.

Level of education of the owner and the success of rural non-farm enterprises

Figure 1 shows the level of education of the owners of rural non-farm enterprises when cross-tabulated with the scale of the enterprise turnover per month. The level of education is one of the determining factors for success of the rural non-farm sector. The more educated people occupy the higher paying jobs in the rural non-farm sector, while the less educated are found in the 'refuge' jobs (see Ministry of Trade and Industry, Cooperatives and Marketing 2008). Against this 


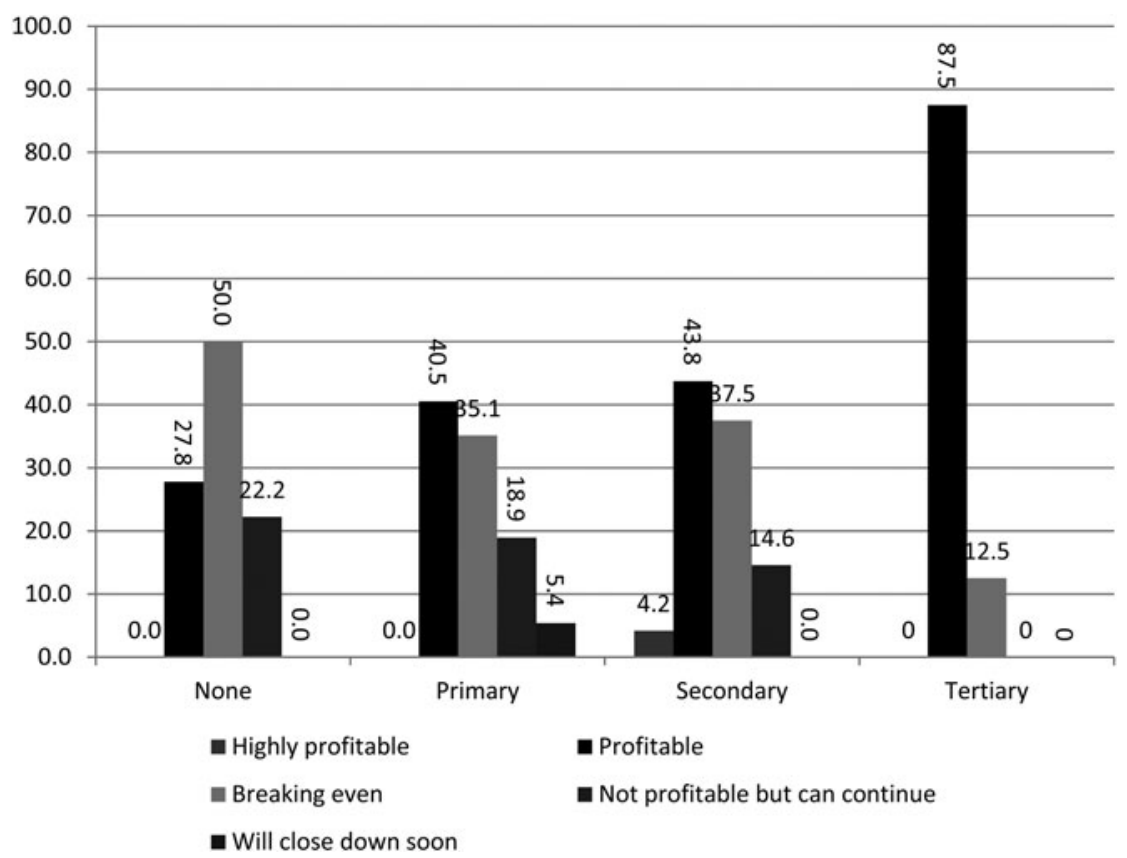

Figure 1. Level of education and the performance of non-farm enterprises in Lesotho, 2010.

background, the following Figure 1 presents results showing the profitability of the rural non-farm enterprises when cross-tabulated with the level of education of the entrepreneurs.

It can be observed from Figure 1 that $87.5 \%$ of rural non-farm enterprises owned by people with tertiary education are rated as profitable or highly profitable. This relatively high rating of profitability is considerably higher than the $27 \cdot 8 \%$ for those without any education; $40 \cdot 0 \%$ for those with primary education; and $43.8 \%$ for those with secondary education. The profitability of enterprises owned by people with a high educational level can be linked to different factors. First, people with a high educational level are in a position to adopt innovations and techniques of production through reading and from other sources. Therefore, they can make informed decisions about their businesses (Bwisa et al. 2011; Martey et al. 2013). Second, it is assumed that it is easier for educated people to establish markets and financial sources for their businesses compared with the less educated. It is therefore suggested that education, as one of the entrepreneurial characteristics, determines the profitability of rural non-farm enterprises (Kolawole \& 
Torimiro 2005; Sarwoko et al. 2013). It can thus be inferred that the contribution of people with a higher level of education to rural development in Lesotho is significant, as they are able to ensure the good performance of rural non-farm enterprises.

In addition to increasing the profitability of enterprises, evidence shows that educational level has an impact on the scale of the average turnover of rural non-farm enterprises. The results showing the scale of the average turnover of rural non-farm enterprises when cross-tabulated with the educational level of entrepreneurs is presented in Table III.

The results in Table II are in line with international trends that education plays an important role in the sound performance of enterprises. In this respect, enterprises owned by people with tertiary education have the highest turnover per month, M8,705.88 compared with the ones owned by those with secondary education, with an average turnover of $\mathrm{M}_{3}, 414^{*} 4^{2}$; those owned by people with primary education have a turnover of $\mathrm{M}_{1}, 826 \cdot 94$; while those owned by those without education have $M_{1}, 818 \cdot 18$. It can therefore be deduced that people with a higher educational level contribute positively to rural development in Lesotho. This is because the educated have literacy and basic numeracy skills that enable them to manage and run their own businesses.

The employment results show that the size of rural non-farm enterprises differs with the level of the owner's education. For instance, in 2010 rural non-farm enterprises employed an average of 1.6 full-time and part-time employees with low levels of education (those with no education, primary and secondary) compared with 0.5 people with tertiary education. These results are in line with the research findings by Bowen et al. (2009) that small-scale enterprises employ many people with low levels of education.

It can be noted from the above discussion that rural non-farm activities play an important role in rural development in Lesotho. The rural non-farm sector contributes a larger share to national development relative to subsistence agriculture. In addition, many Basotho depend on migrant labourer remittances for making a living. However, with an increasing loss of jobs by Basotho men from the South African mines, the country is now confronted with increasing poverty, unemployment and food insecurity. In this regard, non-farm activities are considered a solution to the above social problems. The following section studies the main reasons for the establishment of nonfarm enterprises. 


\section{TABLE III}

The average turnover of non-farm enterprises by level of education of entrepreneurs in Lesotho, 2010

\begin{tabular}{|c|c|c|c|c|c|c|c|c|c|c|}
\hline \multirow[b]{3}{*}{ Turnover } & \multicolumn{8}{|c|}{ Level of education } & & \\
\hline & \multicolumn{2}{|c|}{ None } & \multicolumn{2}{|c|}{ Primary } & \multicolumn{2}{|c|}{ Secondary } & \multicolumn{2}{|c|}{ Tertiary } & \multicolumn{2}{|c|}{ Total } \\
\hline & $\mathrm{N}$ & $\%$ & $\mathrm{~N}$ & $\%$ & $\mathrm{~N}$ & $\%$ & $\mathrm{~N}$ & $\%$ & $\mathrm{~N}$ & $\%$ \\
\hline$<\mathrm{M}_{1}, \mathrm{OOO}$ & 7 & $63 \cdot 6$ & 17 & $65 \cdot 4$ & 14 & $4^{\mathrm{o} \cdot \mathrm{O}}$ & 1 & $5 \cdot 9$ & 39 & $43 \cdot 8$ \\
\hline 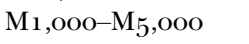 & 3 & $27 \cdot 3$ & 8 & $30 \cdot 8$ & 10 & $28 \cdot 6$ & 5 & $29 \cdot 4$ & 26 & $29 \cdot 2$ \\
\hline $\mathrm{M}_{5}, \mathrm{OO1}-\mathrm{M}_{10,000}$ & 1 & $9 \cdot 1$ & o & o & 11 & $31 \cdot 4$ & 7 & $4^{1 \cdot 2}$ & 19 & $21 \cdot 3$ \\
\hline $\mathrm{M}_{10,001-\mathrm{M} 2 \mathrm{O}, \mathrm{OOO}}$ & o & o & 1 & $3 \cdot 8$ & o & o & 3 & $17 \cdot 6$ & 4 & $4 \cdot 5$ \\
\hline $\mathrm{M}_{20,001-\mathrm{M}_{5} \mathrm{o}, 000}$ & o & o & o & o & o & o & 1 & $5 \cdot 9$ & 1 & $1 \cdot 1$ \\
\hline $\mathrm{M}_{5} \mathrm{O}, \mathrm{OOO}>$ & o & $\mathrm{o}$ & $\mathrm{o}$ & o & o & 0 & o & o & o & 0 \\
\hline TOTAL & 11 & 100 & 26 & 100 & & 100 & & 100 & $89^{2}$ & $99 \cdot 9$ \\
\hline Average turnover & \multicolumn{2}{|c|}{$M_{1}, 818 \cdot 18$} & \multicolumn{2}{|c|}{$\mathrm{M}_{1}, 826 \cdot 94$} & \multicolumn{2}{|c|}{$M_{3,414} \cdot 4^{2}$} & \multicolumn{2}{|c|}{$\mathrm{M} 8,7 \mathrm{O}_{5} \cdot 88$} & \multicolumn{2}{|c|}{$\mathrm{M}_{3}, 764 \cdot 00$} \\
\hline
\end{tabular}

Source: Field data.

REASONSFOR THE ESTABLISHMENT OF NON-FARM ENTERPRISES

A significant percentage of rural people establish rural non-farm enterprises to diversify their livelihood options (Ellis 1998). In addition, pull and push factors are also considered as the main determinants for establishment of non-farm enterprises. The pull factors are associated with some better paying activities in the non-farm sector, while the push factors are related mainly to the decline in agricultural productivity (Reardon 1997). An assessment of the reasons for the establishment of non-farm enterprises in Lesotho shows that non-farm activities are not just for diversifying the livelihood options or ensuring better remuneration activities, but they are an issue of survival. Lack of employment opportunities in Lesotho forces many people to participate in non-farm enterprises. Unemployment rate is very high in Lesotho, estimated at $25 \%$ (Bureau of Statistics 2009). Against this background, the three main reasons for the establishment of rural non-farm enterprises are discussed below, these being poverty, decline in agricultural productivity and supplementing incomes from the formal sector.

POVERTY AND LACK OF EMPLOYMENT OPPORTUNITIES

Poverty can be defined as an inability to attain a minimal standard of living measured in terms of basic consumption needs; or an income 
required to satisfy them; or an inability of individuals, households or an entire community to possess sufficient resources to satisfy their basic needs (World Bank 1990). The qualitative assessment of poverty is further confirmed by the contextualisation of poverty by the International Labour Organisation (2012). The International Labour Organisation (ILO) indicates that the incidence of poverty is extremely high in Lesotho, where about $5^{6.3} \%$ of people live below the poverty line; a factor which forces people to look for opportunities outside agriculture (see Lay et al. 2008).

Poverty seems to be one of the motivations for the involvement of individuals in rural non-farm activities. Responses such as: 'I could not get enough food for my family, and I decided to weave hats using grass for sale' (Mabitle 2010 int.) and 'it was very difficult to buy my children some clothes before I sell some traditional herbs' (Paamo 2010 int.) were common among the answers. The above quotations indicate that a lack of basic needs, such as food and clothes are key contributors to an involvement in the non-farm sector. Closely related to poverty is the high unemployment rate in Lesotho. The following response from one of the interviewees affirms this position when stating: 'it is not very easy to get employment in Lesotho, especially when one is uneducated'.

DECLINE IN AGRICULTURAL PRODUCTIVITY

A second reason (not dissociated from the poverty-related reasons provided above) is related to a decline in agricultural productivity. There are different reasons that have caused a decline in agricultural productivity in Lesotho, subsequently pushing people into non-farm activities. Three distinct factors should be mentioned. First, severe drought that often results in food insecurity is often cited. For example, one respondent said: 'I could not get enough from my land because of severe drought that often affect subsistence production. I then quit farming and participated in brick making' (Lesia 2010 int.). Second, a historical exodus of many Basotho to South African gold mines, plantations and industries left farming in the hands of women and children (Modo 2001). At the same time there is also evidence of migrant labour supporting agriculture in Lesotho (Wallman 1972). Overall, there is little doubt that declining agricultural production in Lesotho has forced people into non-farm activities, such as beer brewing, brick making, the construction of houses, thatching and weaving hats (Senaoana 
et al. 1984). Although decline in agricultural productivity has forced people into non-agricultural activities, the evidence shows that the Lesotho Highlands Water Project implemented rural development projects in the highlands of Lesotho to improve the lives of the mountain people. According to Ramaili \& Cloete (2008), reduction in the number of livestock in the mountain areas was advocated by the Lesotho Highlands Development Authority (LHDA) because it degrades the rangelands. In addition, mountain horticulture and crop production projects were introduced to ensure food security (see Ramaili \& Cloete 2008).

Third, soil erosion has contributed to a shortage of land by decreasing arable land from $13 \%$ at independence to $9 \%$ today (Love 2007). Other studies indicate that declining arable land in Lesotho has resulted in about $40 \%$ of the population not having access to land for cultivation (Makenete et al. 1998; Central Bank of Lesotho 2003). One respondent whose land was affected by soil erosion said: 'My agricultural land has shrunk from 6 to 4 acres because of soil erosion. I no longer get enough maize that can maintain my household to the next harvest season. I then decided to establish a fruit and vegetable business to supplement the meagre agricultural produce' (Ramakhula 2010 int.).

SUPPLEMENTING INCOMES FROM THE FORMAL SECTOR

There is also evidence that rural non-farm enterprises are being established to supplement incomes from the formal sector. A number of permutations of this scenario exist. First, some people establish enterprises operating full-time, while they are also working in the formal sector. For example, one respondent said: 'I am working as a secretary in government, and established a hair salon to supplement my income' (Kepanyane 2010 int.). Second, some respondents use their spare time to engage in income-generating activities. The following response affirms this: 'I work as a motor mechanic for one private company, but on weekends and holidays I provide my services to people who need help and earn some extra money' (Mohapi 2010 int.). These interviews suggest that multiple incomes are commonly found in Lesotho and that the rural non-farm sector is a main source in this respect. The results also suggest that people are not only pushed into non-farm enterprises by unfavourable climatic conditions or unemployment, but because of low remuneration in the formal sector. 
Many Basotho households depend on migrant labourer remittances for making a living. However, with the recent downscaling in the South African gold mines, many families are confronted with food insecurity. As a result, people participate in non-farm activities to make a living. In this respect, the contribution of non-farm activities to rural development in Lesotho is increasing. People use non-farm incomes to finance subsistence agriculture and purchase the basic needs for their families. Although rural non-farm activities contribute positively to rural development in Lesotho, the sector is confronted with many challenges. The assistance of the Lesotho government to improve the available non-farm activities is highly encouraged. This is because the sector employs mostly the less educated people in society. In this regard, poverty, unemployment and food insecurity would be reduced. Furthermore, when the sector is supported, the number of migrant labourers working in South African industries and plantations will be reduced. The retrenched mineworkers will also have alternative sources of making a living in Lesotho.

\section{NOTES}

1. Loti (plural = maloti) was equivalent to US\$10 in 2010 .

2. Some entrepreneurs did not answer the question on turnover.

\section{R E F E R E N C E S}

Arghiros, D. \& J. Moller. 20oo. 'Thai rural enterprise development strategies in the 1990s: a critical appraisal', SOJOURN 1 $5,2: 153-83$.

Awoyemi, T., A. Idowu, B. Omonona, \& A. Falusi. 201 1. 'Non-farm income diversification and poverty among rural farm households in Southwest Nigeria', European Journal of Social Sciences 21, 1: $163-76$.

Balisacan, A., P. Lanjouw, K. Stamoulis, J. Taylor \& T. Reardon. 20oo. 'Effects of non-farm employment on rural income inequality in developing countries: an investment perspective', Journal of Agricultural Economics 51, 2: 266-88.

Berdequé, J., T. Reardon, C. Barrett \& K. Stamoulis. 2007. 'Household income diversification into rural non-farm activities', in S. Haggblade, P. Haell \& T. Reardon (eds), Transforming the Rural Non-Farm Economy. Baltimore, MD: John Hopkins University Press.

Beyene, A. 2008. 'Determinants of off-farm participation decision of farm households in Ethiopia', Agrekon 47, 1: 140-61.

Bowen, M., M. Morara \& S. Mureithi. 2009. 'Management of business challenges among small and micro enterprises in Nairobi-Kenya', KCA Journal of Business Management 2, 1: 16-31.

Bureau of Statistics. 2009. 2008 Lesotho Integrated Labour Force Survey. Maseru, Lesotho.

Bwisa, H., J. Kihoro \& J. Gathenya. 201 1. 'Interaction between women entrepreneurs' age and education on business dynamics in small and medium enterprises in Kenya', International Journal of Business and Social Science 2, 15: 265-72.

Central Bank of Lesotho. 2003. Annual Report for 2002. Maseru: Government Printers. 
Chuta, E. \& C. Liedholm. 1979. Rural Non-Farm Employment: a review of the state of the art. East Lansing, MI: Michigan State University.

Cobbe, J. 1983. 'The changing nature of dependence: economic problems in Lesotho', Journal of Modern African Studies 2 1, 2: 293-310.

Crush, J. (ed.). 2002. 'The border within: the future of the Lesotho-South African International Boundary', Migration Policy Series No. 26. Cape Town: Idasa.

Crush, J. \& D. McDonald. 20oo. 'Transnationalism, African immigration, and new migrant spaces in South Africa: an introduction', Journal of African Studies 34, 1: 1-19.

Crush, J., B. Dodson, J. Gay, T. Green \& C. Leduka. 2010. Migration, Remittances and 'Development' in Lesotho, Southern African Migration Programme. Cape Town: Idasa.

Cunguara, B., A. Langyintuo \& I. Darnhofer. 201 1. 'The role of nonfarm income in coping with the effects of drought in southern Mozambique', Agricultural Economics 42: 701-13.

Dary, S. \& N. Kuunibe. 201 2. 'Participation in rural non-farm economic activities in Ghana', American International Journal of Contemporary Research 2, 8: 154-61.

Davis, J. 2003. The Rural Non-Farm Economy, Livelihoods and their Diversification: issues and options. The Natural Resource Institute: The University of Greenwich.

Dixon, C. 1990. Rural Development in the Third World. London: Routledge.

Driver, T. 1999. 'Anti-erosion policies in the mountain areas of Lesotho: The South African Connection', Environment and History $5: 1-25$.

Elkan, W. 1980. 'Labor migration from Botswana, Lesotho and Swaziland', Economic Development and Cultural Change 28, 3: 583-96.

Ellis, F. 1998. 'Household strategies and rural livelihood diversification', Journal of Development Studies $35,1: 1-38$.

Ellis, F. 200o. 'The determinants of rural livelihood diversification in developing countries', Journal of Agricultural Economics 51, 2: 289-302.

FAO. 1977. Senqu River Agricultural Extension Project Phase I: Rural Sociology Technical Report. Document prepared for the Government of the Kingdom of Lesotho: Maseru.

Ferguson, J. 1985 . 'The bovine mystique: power, property and livestock in rural Lesotho', Man, New Series 20, 4: 647-74.

Ferguson, J. 1990. The Anti-Politics Machine: 'development', depoliticization and bureaucratic state power in Lesotho. Cambridge: Cambridge University Press.

Ferguson, J. \& L. Lohmann. 1994. 'The anti-politics machine "development" and bureaucratic power in Lesotho', The Ecologist 24, 5: $176-81$.

Haggblade, S., P. Hazell \& T. Reardon. 2010. 'The rural non-farm economy: prospects for growth and poverty reduction', World Development 38, 10: 1429-41.

Holden, S., B. Shiferaw \& J. Pender. 2004. 'Non-farm income, household welfare, and sustainable land management in less-favoured area in the Ethiopian Highlands', Food Policy 29: 369-92.

Hymer, S. \& S. Resnick. 1969. 'A model of an agrarian economy with non-agricultural activities', American Economic Review 59, 4: 493-5o6.

Idowu, A., A. Banwo \& E. Akerele. 2011 . 'Non-farm activities and poverty among rural farm households in Yewa Division of Ogun State', Journal of Social Science 26, 3: 21 7-24.

International Labour Organisation. 201 2. Lesotho Decent Work Country Programme Phase II, 201 2-2OI 7. Making a Decent Work Reality in Lesotho, Launched by the Ministry of Labour and Employment, workers' and Employers' Organizations. Maseru: International Labour Organization.

Jin, S., K. Deininger \& M. Sur. 2005. 'Sri Lanka's Rural Non-Farm Economy: removing constraints to pro-poor growth'. Paper prepared for presentation at the American Agricultural Economics Association Annual Meeting, July 24-25. Providence, Rhode Island.

Jonasson, E. \& S. Helfand. 2009. 'How important are locational characteristics for rural non-agricultural employment? Lessons from Brazil', World Development 38, 5: 727-41.

Kelly, V., E. Crawford \& T. Reardon. 1994. 'Links between nonfarm income and farm investment in African households: adding the capital market perspective', American Journal of Agricultural Economics 76, 5: $1172-6$.

Kolawole, O. \& D. Torimiro. 2005. 'Participatory rural entrepreneurship development for grassroots transformation: a factor analysis', Journal of Humanities and Ecology 1 8, 3: 193-8.

Kristiansen, S. 2003. 'Linkages and rural non-farm employment creation: changing challenges and policies in Indonesia'. ESA Working Paper No. 03-22. Rome: Food and Agriculture Organization.

Kuiper, M., G. Meijerink \& D. Eaton. 2008. 'Rural livelihoods: interplay between farm activities, nonfarm activities and the resource base', in R. Roetter, H. van Kealen, M. Kuiper, J. Verhagen \& H. 
van Laar (eds), Science for Agriculture and Rural Development in Low-income Countries. New York, NY: Springer Science \& Business Media B.V., 77-95.

Lanjouw, P. 1999. 'Rural non-agricultural employment and poverty in Ecuador', Economic Development and Cultural Change 48, 1: 91-122.

Lanjouw, J. \& P. Lanjouw. 1997. The Rural Non-Farm Sector: an update. Washington, DC: Development Economics Research Group, The World Bank.

Lay, T., O. Mahmoud \& G. M'Mukaria. 2008. 'Few opportunities, much desperation: the dichotomy of non-agricultural activities and inequality in Western Kenya', World Development 36, 12: 2713-32.

Love, R. 2007. 'Lesotho: inner to outer periphery?', Review of African Political Economy, 23 (67): 75-80.

Low, A. 1986. Agricultural Development in Southern Africa: farm households economics and the food crisis. London: James Currey.

Makenete, A., G. Ortmann \& M. Darroch. 1998. 'Food-aid dependency in Lesotho: issues and policy implications', Development Southern Africa $15,2: 25^{1-65}$.

Makhanya, E. 2004. 'Demographic dynamics and land degradation at Ratau, Lesotho, in the context of rural sustainability', Land Degradation and Development 15: 257-69.

Malek, M. \& K. Usami. 2oog. 'Determinants of non-farm income diversification in developed villages of Bangladesh', American Journal of Economics and Business Administration 1, 2: 141-9.

Marais, L. 2013. 'The impact of mine downscaling on the Free State goldfields', Urban Forum 24, 4: $5^{\mathrm{O}} 3^{-21 .}$

Martey, E., K. Annin, C. Attoh, A. Wiredu, P. Etiwire \& R. Al-Hassan. 2013. 'Performance and constraints of small scale enterprises in the Accra Metropolitan Area of Ghana', European Journal of Business and Management 5, 4: 83-93.

McCann, J. 1999. Green Land, Brown Land, Black Land: an environmental history of Africa, I80o-I99o. Oxford: Heinemann.

McDonald, D., L. Zinyama, F. de Vletter \& R. Mates. 200o. 'Guess who's coming to dinner: migration from Lesotho, Mozambique and Zimbabwe to South Africa', International Migration Review 34, 3: $813-41$.

Mensah, S. \& V. Naidoo. 2011 . 'Migration shocks: integrating Lesotho's retrenched migrant miners', International Migration Review 45, 4: $1017-42$.

Ministry of Trade and Industry, Cooperatives and Marketing. 20o8. The State of Small Enterprises in Lesotho: a study undertaken by SBP for the Ministry of Trade and Industry, Cooperatives and Marketing. Maseru.

Modo, I. 2001. 'Migrant culture and changing face of family structure in Lesotho', Journal of Comparative Family Studies 32, 3: 443-52.

Murray, C. 1977. 'High bridewealth, migrant labour and the position of women in Lesotho', Journal of African Law 2 1, 1: 79-96.

Murray, C. 1981. Families Divided: the impact of migrant labour in Lesotho. Cambridge: Cambridge University Press.

Nowak, M. 1989. 'The role of microenterprises in rural industrialisation in Africa', in J. Levitsky (ed.), Microenterprises in Developing Countries: papers and proceedings of an international conference. London: IT Publications: $57-78$.

Quinlan, T. 1995. 'Grassland degradation and livestock rearing in Lesotho', Journal of Southern African Studies 2 1, 3: 491-507.

Ramaili, L. \& F. Cloete. 2008. 'The role of the Lesotho Highlands water project in poverty alleviation in Lesotho', Africa Insight 37, 4: $117-36$.

Rantšo, T. 2014. 'The Role of the Non-Farm Sector in Rural Development in Lesotho'. PhD thesis, University of the Free State.

Reardon, T. 1997. 'Using evidence of household income diversification to inform study of the rural nonfarm labor market in Africa', World Development 25, 5: 735-47.

Rosenberg, S. 2007. 'South African and global apartheid: the experience of Basotho Labor in the South African gold mines and Taiwanese-owned textile factories', Safundi-The Journal of South African and American Studies 8, 4: 459-72.

Sarwoko, E., A. Surachman \& D. Hadiwidjojo. 2013. 'Entrepreneurial characteristics and competency as determinants of business performance in SMEs', IOSR Journal of Business and Management (IOSR$J B M) 7,3: 3^{1-38 .}$

Sebotsa, M. \& L. Lues. 2010. 'An evaluation of the implementation and management of the strategies adopted by the government to improve food security in Lesotho', Journal for New Generation Sciences 9, 2: $43-55$. 
Senaoana, M.P., S.D. Turner \& G. van Apeldoorn. 1984. 'Research on Rural Non-Farm Employment in Lesotho: Results of a Baseline Survey'. Research report 6. Roma: Institute of Southern African Studies, National University of Lesotho.

Spiegel, A. 1980. 'Changing patterns of migrant labour and rural differentiation in Lesotho', Journal of African Studies 6, 2: 1-13.

Start, D. 2001. 'The rise and fall of the rural non-farm economy: poverty impacts and policy options', Development Policy Review 19, 4: 491-505.

Stifel, D. 2010. 'The rural non-farm economy, livelihood strategies and household welfare', African Journal of Agricultural and Resource Economics 4, 1: 82-109.

Sundaram-Stukel, R., K. Deininger \& S. Jin. 2006. 'Fostering growth of the rural non-farm sector in Africa: the case of Tanzania'. Selected paper prepared for presentation at the American Agricultural Economics Association Annual Meeting, July 23-26, Long Beach, California.

Tacoli, C. 1998. 'Rural-urban interactions: a guide to the literature', Environment and Urbanization 10 , $1: 147-65$.

Ulicki, T. \& J. Crush. 20oo. 'Gender, farm work and women's migration from Lesotho to the New South Africa', Canadian Journal of African Studies 34, 1: 64-79.

Ulicki, T. \& J. Crush. 2007. 'Poverty, gender and migrancy: Lesotho's migrant farmworkers in South Africa', Development Southern Africa 24, 1: 155-72.

Wallman, S. 1972. 'Conditions of non-development: the case of Lesotho', Journal of Development Studies 8: $25^{1-61 .}$.

Wallman, S. 1976. 'The modernization of dependence: a further note on Lesotho', Journal of Southern African Studies 3, 1: 102-7.

Ward, M. 1967. 'Economic independence for Lesotho?', Journal of Modern African Studies 5, 3: $355^{-68 .}$

Wellings, P. 1986. 'Lesotho: crisis and development in the rural sector', Geoforum 1 7, 2: $217-37$.

Wilkinson, R. 1983. 'Migration in Lesotho: some comparative aspects, with particular reference to the role of women', Geography 68, 3: 2008-224.

World Bank. 1990. World Development Report I99o. New York, NY: Oxford University Press.

Zuwarimwe, J. \& J. Kirsten. 2011. 'Social networks and rural non-farm enterprise development and implications for poverty reduction among rural households in Zimbabwe', Journal of Geography and Regional Planning 4, 6: 344-54.

\section{Interviews}

Lesia Teboho, business owner-fruits and vegetables, Mazenod, 30.8.2010.

Kepanyane Sello, Business Owner, Roma, 10.7.2010. Interview.

Mabitle mabitle, business owner-carpenter, Mazenod, 30.8.2010. Interview.

Mohapi John, business owner-mechanic, Roma, 16.8.2010. Interview.

Mohai Liteboho, business owner-salon, Roma, 16.8.2010. Interview.

Morake Lefulesele, business owner-retail shop, Roma, 16.8.2010. Interview.

Paamo Moja, business owner-welding, Roma, 16.8.2010. Interview.

Ralejoe Thabiso, business owner-welding, Ha Makhalanyane, 23.8.2010. Interview.

Ramakhula Francis, business owner-welding, 15.11 .2010$. Interview. 